Kisly M.-O.

\title{
CRIMEAN TATARS IN EXILE: COMMUNITY BELONGING AND BEING THE OTHERS
}

As a result of the deportation, the Crimean Tatars became an "unnation" for the regime and unwanted neighbors for local population, particularly the Uzbeks. The deportation ruined the traditional way of life, social structure and cultural institutes of Crimean Tatars. Among the factors that played an outstanding role in the process of preserving the nation identity, religion, traditions, and holidays have constituted the core elements. At the same time, merging of completely different traditions occurred. Narratives recounted within families played a crucial role in both the maintenance of Crimean Tatar memory about their lost Homeland and creation of the image of the promised land. The family was considered as the last stronghold against Russification. Although the Uzbek language is similar to the Crimean Tatar language and was considered as an option of preserving native language, the level of education in Uzbek schools was much weaker than in Russian ones. After 1956, Crimean Tatars began leaving distant places of exile. They were valued as specialists due to their education, knowledge of the Russian language, and experience in working on leading positions in Crimea before the deportation. Due to these changes in the life of Crimean Tatars, they became the ordinary Soviet citizens, if only they had not been stigmatized as traitors and had the right to return home. An accusation of betrayal, the core component of the life of Crimean Tatars in exile, used to take place in the first years of exile and even later. Nevertheless, Crimean Tatars did not assimilate with Uzbeks due to the differences in faith, socio-economic background, education and culture. Crimean Tatars greatly increased their education level and forced the knowledge of Russian language. By the end of the 1980s, Crimean Tatars along with Russians occupied the majority of knowledge-intensive sectors of industry. However, despite the rapid change in their social status, Crimean Tatars remained second-class citizens, being still labeled as traitors. Due to Soviet propaganda that provoked aggressive othering and dehumanization of Crimean Tatars in exile, as well as socio-economic, cultural difference, and colonial status of Uzbekistan, Crimean Tatars were treated as Others by Uzbeks.

Keywords: Crimean Tatars, exile, Uzbekistan, Russification, identity.

The forced relocation of national groups from their traditional areas of settlement, also acknowledged as ethnic cleansing by some scholars, was a widespread phenomenon in the Soviet Union. Indeed, deportation was a common practice in the twentieth-century nationalist projects. However, the Soviet Union was not a nation-state. Soviet authorities practiced forced relocations of different populations defined by class, religion, ethnicity and political affiliation. Total number of the deported by ethnicity was approximately 2 million. ${ }^{1}$

The deportation of Crimean Tatars started right after the liberation of Crimea on May $18^{\text {th }}, 1944$. The reason alleged by the Soviet authorities for this was a collaboration with German and Romanian forces during their three-year occupation of Crimea. Soviet authorities did not try to figure out who had been actually guilty of the collaboration, but instead they deported the entire Crimean Tatar population, not only partisans and party members, but even

${ }^{1}$ Otto Pohl, Ethnic Cleansing in the USSR, 1937-1949 (Connecticut: Greenwood press, 1999), 5. women, children, and the elderly - all those who had not had any connections to the Nazi regime. According to official statistics, the total number of the deported Crimean Tatars was 191,044. ${ }^{2}$ Moreover, Crimean Tatar soldiers who had fought in the Soviet Army were sent to so-called labor army after WWII. They got the opportunity to find their families only after 1948. As the result of the state-organized violence, Crimean Tatars became a nation in exile (Sürgünlik in Crimean Tatar). Their final destinations were Uzbekistan and labor camps in Ural (Molotov oblast, Sverdlov oblast) and the Volga district (Gorky oblast, Mari Autonomous Soviet Republic). ${ }^{3}$ The entire nation was put into the penal camps, socalled special settlements (spetsposelenniia) without any right to leave it even for a funeral of a family member in a nearby camp. First years in exile were marked by high death toll caused by starvation

\footnotetext{
${ }^{2}$ Олег Бажан, ред., Кримські татари: шлях до повернення (Київ: Інститут Історії України, 2004), 71.

3 Николай Бугай, ред., Иосиф Сталин-Лаврентию Берии: «Их надо депортировать». Документы, факты, комментарии (Москва: Дружба народов, 1992), 140.
} 
and diseases and oppression committed by authorities and local population. Thus, Crimean Tatars became an "unnation" for the regime and unwanted neighbors for local populations, particularly the Uzbeks. More than 40 years Crimean Tatars have remained in exile, several generations were born and raised in Uzbekistan and not all of them have returned.

Undoubtedly, the deportation ruined the traditional way of life, social structure and cultural institutes of Crimean Tatars. Before the cancellation of special settlement regime in 1956, the majority Crimean Tatars used to live in distant, mostly rural areas, and work at state-owned farms (radgosp), mines and manufacturing as unskilled workers without decent salaries. Special settlements had a shortage of medical service, schooling (not to mention education in native language) and infrastructure. While talking about this period of time, Crimean Tatars say that they first of all tried to survive. After 1956, Crimean Tatars began leaving distant places of Uzbekistan looking for education (vocational training school, so-called PTU, and later, when it became possible, universities), skilled jobs and better life conditions in cities. Crimean Tatars were valued as specialists due to their education, knowledge of the Russian language, and experience in working on leading positions in Crimea before the deportation. ${ }^{1}$ Due to these changes in the life of Crimean Tatars, they became the ordinary Soviet citizens, if only they had not been stigmatized as traitors and had had the right to return home. Moreover, there was no more such a nation as Crimean Tatars, just citizens of Tatar nationality formerly living in Crimea. ${ }^{2}$ In Western sovietology of 1960s there was a prediction that the Crimean Tatars are going to be assimilated by the local population and disappear from history". 3

Traditionally, historiography has focused on several themes and issues, namely historical fate of Crimean Tatars, ${ }^{4}$ background of deportation, deportation process itself $f^{5}$ and the political struggle of the Crimean Tatars for the return to Crimea per se or

${ }^{1}$ Гульнара Бекирова, Крымскотатарская проблема в СССР (1944-1991) (Симферополь: Оджак, 2004), 76.

2 Greta Uehling, Beyond memory: the Crimean Tatars' deportation and return (New York: Macmillan, 2004), 208.

${ }^{3}$ Brian G. Williams, "A Community Reimagined. The Role of 'Homeland' in the Forging of National Identity: The Case of the Crimean Tatars," Journal of Muslim Minority Affairs 17, 2 (2007): 238.

${ }^{4}$ Alan Fisher, The Crimean Tatars (Stanford: Hoover Institution press, 1978).

${ }^{5}$ J. Otto Pohl, "The Deportation and Fate of the Crimean Tatars". Paper presented at the 5th Annual World Convention of the Association for the Study of Nationalities, New York, April 2000. within the framework of the dissident movements in the USSR. ${ }^{6}$ Such aspects of exile as everyday life, gender, and childhood are still marginalized. At the same time, despite the fact that studies dealing with concepts of memory, homeland, assimilation and identity are nurtured within irreproachable methodological background, they either lack data from fieldwork or prone to limit voices of respondents (or 'companions', according to a new vision of Oral History methods). ${ }^{7}$ However, a number of remarkable researches with a great contribution to the understanding of Crimean Tatars exile and return are used in this paper. ${ }^{8} 910$

The proposed paper is based on my fieldwork conducted between 2013 and 2018 in Crimea with informants formerly living in Uzbekistan ${ }^{11}$ (except of Lyoman, whose family was deported to Ural and they moved to Uzbekistan in 1958, when he was twenty years old) and born between 1928 and 1975 . The total number of interviews used in the paper is 28. I used a method of snowball sampling (asking interviewees to recommend others for an interview), thus no selection of respondents appropriate to a certain level of education or occupation was made. Therefore, the paper contains the narratives of $\mathrm{Na}$ tional Movement activists, teachers, artists and manual workers. During mentioned years, I have been engaged in different research projects which topics varied from the childhood of deported Crimean Tatars (so-called Postgeneration) and to their return to the Homeland. The in-depth and semi-structured questionnaire used during the interviews consists of core questions on memory of deportation, homeland, and return. Interviews were conducted in Russian as one of the most appropriate languages for both the informants and the author.

The paper reveals and analyzes some aspects concerning self-perception of Crimean Tatars and being the Others. The other goal of the paper is to examine the issue of assimilation and Russification (or Sovietization) of Crimean Tatars in exile. Although the paper addresses the question of identity to some extent, it is worth emphasizing that the is-

${ }^{6}$ Гульнара Бекірова, Півстоліття опору: Кримські тата ри від вигнання до повернення (1941-1991) роки). Нарис політичної історії (Київ: Критика, 2017).

${ }^{7}$ Ayşegül Aydıngün, Erdoğan Yıldırım, "Perception of Homeland among Crimean Tatars: Cases from Kazakhstan, Uzbekistan and Crimea", Bilig, 54 (Summer 2010).

${ }^{8}$ The Tatars of Crimea: Return to the Homeland, ed. Edward Allworth (Durham and London: Duke University Press, 1998).

9 Brian Williams, The Crimean Tatars. From Soviet genocide to Putin's conquest (New York: Oxford University Press, 2016).

${ }^{10}$ Uehling, Beyond memory.

${ }^{11}$ As a majority of Crimean Tatars were deported to Uzbekistan and because coexistence with Uzbeks - Muslims and Turks is also in a focus of research. 
sue of forging and reshaping of Crimean Tatars identity in exile as well as the examination of factors crucial in this process are not in the focus of this work, since these questions deserve a full-length research to be published in the nearest future. Thus, the assignments of this paper are as follows: to examine such aspects of identity as religion, traditions and language, to highlight the issue of the lost Homeland, to analyze othering by local population in Uzbekistan and emphasize Auto Sovietization in exile.

\section{Societal and Cultural context of Crimean Tatars' Self-Awareness}

It is widely recognized that identities have been constructed around a common religion and language shared by community members. Islam became the main religion on peninsula during Crimean Khanate period and afterward was reviewed by Ismail Bey Gasprinski`s ideas of modern nationalism. Moreover, social and cultural traditions of the Crimean Tatars were forged in accordance with Islam. Regarding Crimean Tatar language, it was supported to a large extent in pre-war Crimea as a key aspect of Soviet "nation-building" policy. During the early Soviet period due to korenizatsiia Crimean Tatar language was promoted as a state language of Crimean ARSR along with Russian. ${ }^{1}$ According to recalls, before deportation even Russians and Ukrainians in Crimea spoke Crimean Tatar language. ${ }^{2}$ In concordance with core questions of surveys used in this paper, socio-cultural aspects is limited to religion, traditions, holidays and language.

When speaking about religion, we have to keep in mind that due to the prosecution of Crimean Tatars by the Soviet authorities and post-traumatic syndrome obtained after the deportation, religious practices have not been accepted widely and consisted of some very general practices as celebration of Uraza Bayrami and Kurban Bayrami, although some families avoided even these holidays. One of the most significant reasons of avoiding Muslim holidays was the Soviet anti-religious policy: "We lived according to the Soviet rules". ${ }^{3}$ Therefore, those religious families who followed religious prescriptions and read the Koran had a strong fear of punishment and persecution by the authorities and the KGB, so that they had to hide their religious beliefs and practices. Secondly, traditions were forgotten in some families, since grandparents as the main

\footnotetext{
${ }^{1}$ Williams, The Crimean Tatars. From Soviet genocide, 74

${ }^{2}$ Ediye, 1963. Interview by author. 15 August 2015.

${ }^{3}$ Nariman, 1962. Interview by author. 15 August 2015.
}

guardians of the national traditions and family traditions had passed away.

During the Soviet time, a Mullah elected by dwellers of a Crimean Tatar village could be any man of a certain age having the best knowledge of the Koran, though without any special theological education. Besides, according to Crimean Tatar Muslim traditions, such rites as Nikah (marriage) and male circumcision are usually performed at one's home within the family circle, in contrast to Christian traditions with a parish church as the center of a community's religious life. ${ }^{4}$

Those families whose elders had survived were indeed fortunate, because they did fasting and made Namaz, serving as an example for those generations born in Asia.

I want to say that our grandfather was a Mullah and he was able to read the Koran, and my mother also read the Koran in Arabic. Grandfather did this, even when it was not allowed in the Soviet times. He did fasting (Uraza), made Namaz. When he came to us, he did it five times a day. We knew the most common prayers, even if we didn't understand what they meant, but we always read it. ${ }^{5}$

For the majority of families religion was only a tradition without its sacred meaning. On the one hand, as mentioned above, soviet antireligious policies influenced Muslims and particularly Crimean Tatars. On the other hand, it was a result of both the secularization and crucial shift in the nation identity provoked by activity of Ismail Gaspirali and Young Tatars (Mladotatary) before the revolution of $1917 .^{6}$ Although Crimean Tatars experienced impact of different religious schools from Turkey and Arabic countries after their return to the Homeland, they insist that their nation has never been so religious as their neighbors.

Due to the deportation, many rituals, religious traditions were lost. The elderly died. If they were able to teach children - this is good. And we worked at that time, we did not have time. And when we came back here, everybody wanted to teach us their religion. Turks - their own, Tatarstan - their own, Arabs - their own. So, when we have debates on the "covering faces" issue, I say: "This is not ours." Even when you take a look at some old pictures. Nobody hid their faces, they put on feskas. ${ }^{7}$

${ }^{4}$ Олена Соболева, «Ісламські традиції у весіллі кримських татар кінця 19 - початку 20 століття», Етнічна історія народів Европи 25 (2008): 75.

5 Venera, 1959. Interview by author. 30 October 2013.

6 Williams, "A Community Reimagined", 232.

${ }^{7}$ Zuriye, 1968. Interview by author. 29 July 2017. 
One of the old Muslim traditions, peculiar to Crimean Tatars, that has been preserved in exile was to show respect to the elders in the family. During the big festivals, the younger family members used to visit their parents and grandparents to kiss their hands. Children received sweets and money as a gift. In many Crimean Tatar families parents and grandparents died during the deportation or the first years of the exile. As a result, some of Crimean Tatars during holidays visited other members of family or even local Uzbeks elders.

Uzbeks didn't have such a tradition, it was ours. Uzbeks used to come to someone's house, return thank shortly and go to the next house. But we, the Crimean Tatar youth, we were kissing the elder's hands and they treat us with something special. Every family was cooking for 3 days to be prepared! At the end, we were returning home with bags full of treats and pockets full of kopeyki. ${ }^{1}$

Only a few traditions pertaining to religious rites were maintained, while all other traditions have been reconstructed later step by step by those who had not been religious persons previously, though it sounds paradoxically.

Friday received the special treatment. There were many traditions, such as do not leave the laundry to line dry after sunset, do not sweep, that is all housework must be done before the sunset, absolutely all. It was not allowed to do the laundry on Friday. So, this was respected somehow, although my parents, actually, my mother was a komsomolka, and my father was a sailor. He was indeed an atheist. Then, he became one of the main mullahs with age. He sang the prayers so beautifully!... Things go back to the way they were after all... You know, even not as religion but traditions, all these things were respected in our family. ${ }^{2}$

Concerning feasts and holidays, we can also trace the diffusion of different cultural traditions among informants. For example, Nawruz, a holiday of the first day of spring and a widespread feast in Central Asia, became celebrated among Crimean Tatars

I remember that there was Nawruz Bayram in Uzbekistan. Crimean Tatars call it Navrez. So, we celebrated it because our neighbors were Uzbeks.

\footnotetext{
${ }^{1}$ Osman, 1967. Interview by author. 12 August 2015.

${ }^{2}$ Shefika, 1950. Interview by author. 10 August 2015.
}

They prepared some special meal, samanu ${ }^{3}$, their national meal. They used to invite us to eat. ${ }^{4}$

Regarding such Christian feasts as Christmas and Easter, celebrated by local Orthodox Russians, ${ }^{5}$ Crimean Tatars did not adopt them (and they are still absent in Crimea among Crimean Tatars), although they could celebrate these Orthodox feasts because of being good neighbors: "We painted Easter eggs. Neighbors are happy and we are happy as well". ${ }^{6}$. Probably, being good neighbors for a Russian community of Uzbekistan was the only reason why Crimean Tatars could have participated in Easter rituals of Christians. It should be mentioned that despite anti-religion policy, Easter was extremely popular ("proletarians of all countries are united around the Easter table"). Something similar can be traced in the memories of Liliya. She tells that her family celebrated Easter:

We celebrated the 1st of May and Easter. On Easter, mama used to bake Easter cakes all night. People came to us, they said "Christ is risen!". And we answered, "Truly he is risen!". 7

As we can see, a wide variety of festivals took place in Uzbekistan. As a result, some of Crimean Tatars are confused now about holidays they used to celebrate while they were in exile:

...New Year's Eve, perhaps. I remember we went with my friends singing Christmas carols. Maybe it was on the eve of the Old New Year? ${ }^{8}$ Or on Uzbek Boychechak? I don't remember clearly...

Old New Year was a popular holiday in the Soviet Union among the Orthodox believers. Boychechak, literally Snowdrop flower, is an Uzbek spring song for Nawruz, a holiday of the first day of the New Year in Persian calendar. From the aforementioned memories of Lenura, we can assume that the merging of completely different religion traditions was a result of the social environment in which Crimean Tatars lived. Influenced by the Soviet milieu, Lenura thus seemed to perceive cultural borrowings as some usual pattern.

\footnotetext{
3 Traditional sweet dish made from germinated wheat.

4 Venera, 1959.

5 According to respondents. In fact, it consisted not only of ethnic Russians, but of different Slavic nation of USSR, including Ukrainians.

${ }^{6}$ Refat, 1975. Interview by author. 29 July 2015.

${ }^{7}$ Liliya, 1953. Interview by author. 10 January 2014.

${ }^{8}$ The Old New Year or the Orthodox New Year is an informal traditional holiday, celebrated as the start of the New Year by the Julian calendar. In the 20th century, the Old New Year falls on January 14 in the Gregorian calendar.

${ }^{9}$ Lenura, 1946. Interview by author. 9 January 2014.
} 
Before the deportation Crimean Tatars had not been accustomed to celebrate birth dates. Instead, they had an initiation ceremony that has remained widespread in exile:

I like the initiation rite very much, this ritual is very complicated... and it is customary to name children not in accordance with the holy books - though we do it - but to commemorate relatives that passed away. So, such names give you some status, a kind of responsibility to be a decent person. And it just comes naturally that I have five male grandsons named after their grandfather and great-grandfather. $^{1}$

Wedding ceremony was an extremely popular ritual among Crimean Tatars in exile, first of all because it was a good occasion for a whole family to see each other. Suffice it to say that even militia and a disguised KGB agent visited Crimean Tatar wedding parties on purpose to disclosure Crimean Tatar National Movement activists. ${ }^{2}$ As noted above, Crimean Tatars do not need a mosque to perform their religious rituals, instead a mullah comes to the bride's house. An old Muslim tradition, when women and men celebrated separately - and previously it was widespread in Crimea - had disappeared. At the same time, the tradition of separate celebration by elders and youth was preserved.

Weddings were celebrated on a very high level, it was an important event. We invited musicians. Firstly, the elders gathered, usually they were asking for an old Crimean Tatar music. A musician who can play an old music was very respected. In the afternoon, this part came to the end and seniors went home. Instead, in the evening the celebration for youth starts. With a live music as well. Not like nowadays when they conduct weddings with a laptop. ${ }^{3}$

As we can see, music was a significant part of Crimean Tatar life. As some respondents mentioned, local population, Uzbeks really loved Crimean Tatar weddings for live music. Although some researchers argue that high culture was preserved due to celebrated Crimean Tatar composers, singers and danc$\mathrm{ers}^{4}$, it can be seen from the interviews that products of high-culture (such as gramophone records or tickets to a concert in Tashkent) were unavailable to the majority of exiled Crimean Tatars. At the same time the role of folklore cannot be underestimated.

\footnotetext{
1 Shefika, 1950.

2 Osman, 1967.

3 Nariman, 1962.

4 Riza Gülüm, "Rituals: Artistic, Cultural, and Social Activity," in The Tatars of Crimea: Return to the Homeland, ed. Edward Allworth (Durham and London: Duke University Press, 1998), 84.
}

And they sang, you know, not as we do now singing loudly. But if you sing, you must please not only yourself but your listeners as well. My mother had a lovely voice, and all these modulations, melodies. Many played musical instruments: trumpet, violin. My mother played the piano, and she played the mandolin when she was younger. We have a large number of musicians, although our nation seems to be a hard-working one, agricultural. ${ }^{5}$

It should be mentioned that among Crimean Tatars not only traditional holidays and religious rites but also Soviet holidays remained popular. Statesponsored attempts to demolish traditional rituality led to privatization of Soviet festivities. In this manner, for example First of May, Pervomay, (Workers Day) became family holidays ("Father drove us to the countryside on May 1 and November 7. We had a motorcycle with a sidecar" ${ }^{\text {") }}$ instead of political demonstrations. ${ }^{7}$ Moreover, even Election Day was perceived as a holiday ("We used to make shashliki (barbeque) with our friends, not like now" ${ }^{\text {). While }}$ talking about Soviet holidays informants usually mention entertainment component as a new rituality: air balloons, banners, songs and finally - ice cream and a marry-go-round for kids.

On May 1 parents always bought new shoes and a new dress and went to the demonstration. When we were children, we went to parades with parents, they took us with them. ${ }^{9}$

Big Crimean Tatars families, so-called extended families, played an important role in keeping not only their folklore culture but also their mother tongue language. The family was considered as the last stronghold against Russification. ${ }^{10}$ According to Greta Uehling, most Crimean Tatars report that Crimean Tatar is their native language, but if the question is about what language they actually speak at home or at work, or which language they "think" in, responses suggest more linguistic Russification. ${ }^{11}$ According to linguistic, former exiles have spent so much time in a Russian-speaking

\footnotetext{
5 Shefika, 1950

6 Zera, 1959.

Катриона Келли, Светлана Сироткина, «Было непонятно и смешно: Праздники последних десятилетий советской власти и восприятие их детьми», Антропологический форум 8 (2008): 260

${ }^{8}$ Liliya, 1953.

${ }^{9}$ Venera, 1959

${ }^{10}$ Mubeyyin Altan. "Structures: The importance of family - the personal memoir," in The Tatars of Crimea: Return to the Homeland, ed. Edward Allworth (Durham and London: Duke University Press, 1998), 101

${ }^{11}$ Greta Uehling, "Having a Homeland: Recalling the Deportation, Exile and Repatriation of Crimean Tatars to their Historic Homeland" (PhD diss., University of Michigan, 2000), 71.
} 
dominant society and most of them were educated in Russian, so they speak idiomatically and do not generally make grammatical errors. In addition, the usage of Crimean Tatar language is limited to the domestic sphere, so their possibilities for interference in lexicon are constrained. ${ }^{1}$

My grandmother spoke Crimean Tatar to us, and we answered in Russian. I think in Russian and formulate thoughts in Russian. Of course, as far as possible, I use the Crimean Tatar language. ${ }^{2}$

Also, the Crimean Tatars parents faced the dilemma of choosing a school for their children. It was believed that Russian schools in Uzbekistan had better standards. On the other hand, assimilation of the youngsters was less likely in Uzbek schools. Shefika recalls that instead of an Uzbek school, parents sent her to a Russian one:

Before school, I did not speak Russian, I spoke Crimean Tatar and parents seriously considered which school I should attend, Russian or Uzbek. They were ready to send me to Uzbek not to let me get assimilated. And now it is easy to understand what school Crimean Tatars attended. Especially when it was a village, there were no Russian schools. But Uzbek one was weaker, so parents send me to the Russian school. ${ }^{3}$

At the same time, there were families in which either parents spoke Russian or environment was Russian-speaking. Respondents from such families used Crimean Tatar language very rarely and they admit that it is much easier for them to think in Russian and then translate it into their native language.

Majority of respondents mention that they spoke only Crimean Tatar language at home.

The language was obviously monitored closely. We spoke only our native language within our family; that is, you can speak any language you want outside, but we speak only our native language after setting foot in our house. ${ }^{4}$

It is also believed that Uzbek language helped Crimean Tatars not to lose their language, since both languages have some similar features, though Uzbek language had an influence on the purity of Crimean Tatar language. ${ }^{5}$

To sum up, it needs to be said, although religious rites had been waning during prewar period and after deportation due to a number of reasons, such holidays as Uraza Bayram and Kurban Bayram

\footnotetext{
1 Mica Hall, "Russian as spoken by Crimean Tatars" (PhD diss. University of Washington, 1997), 162.

2 Lenura, 1946.

3 Shefika, 1950.

Ibid.

Nariman, 1962
}

have not lost their importance. Moreover, Crimean Tatars saved a certain amount of traditions and everyday practices connected with constants of Islam though losing their sacred meaning. Concerning holidays, a popular in Central Asia feast of Nawruz was taken as well as a new rituality of Soviet holiday. Language issue had a great importance for exiles who were trying to save their mother tongue language. Unfortunately, there was no education in Crimean Tatar language and parents faced a dilemma because Russian schools had higher level of teaching than Uzbek schools. Thus, the usage of Crimean Tatar language was limited to the domestic sphere, while public sphere was russified.

\section{Family narratives, trauma of deportation and belonging to lost Homeland}

As indicated above, the significance of family in keeping traditions and language cannot be underestimated. In the years after the deportation the issue number one was how to survive and not to die. On the second place, there was the need to unite family members separated by the deportation in 1944. Notwithstanding the strict regime of special settlements, Crimean Tatars succeeded in searching for lost family members. In 1948, those Crimean Tatars who were fighting during the Second World War in the Soviet Army received permission to leave so-called labor army camps and to find their families in Uzbekistan. Their return influenced the life of Crimean Tatars, since their life became better. Mortality went down and birth rate went up. Although in many families grandparents died during the deportation or the first years of exile, Crimean Tatars were trying to keep their families extended. Moreover, Crimean Tatars in exile used to get married only to Crimean Tatars $^{6}$ and to give birth to as many children as possible.

I was asking my mom: "You had a kind of competitions or what? Why not just give birth to three or four?". And my mom replied: "Not of course, you know how many Crimean Tatars died, it is important to recover our people. You should have as much children as possible too"?

Big and extended Crimean Tatars families were the only possible place for stories about the deportation and homeland. The majority of my respondents were born in the 1950s and the 1960s and belong to so-called post-deportation generation, because they did not witness the deportation. Their historical memory about this catastrophe was mainly shaped

\footnotetext{
${ }^{6}$ Altan, Structures, 104

7 Zuriye, 1968
} 
through the narratives circulated within the family. This generation was mostly protected by their parents from the trauma of the deportation, although they obtained some knowledge about deportation from occasional conversations of the adults or from the accusations uttered publicly by the representatives of different nationalities. ${ }^{1}$

Greta Uehling identifies three styles of narratives recounted within families: intensive, selective and reluctant. Intensive style was used for recounting their former lives in Crimea to children "as bedtime stories and mealtime conversation". Children absorbed these stories appropriating them and making them their own over time. The second style, the selective one implied such narrative strategy as "waiting until children reach adolescence and considered ready to understand". The last reluctant style is narrative of silence, which means that parents did not talk at all about Crimea. Greta Uehling argues that both intensive and selective styles were the most widespread among Crimean Tatar families. ${ }^{2}$

The most common way of learning that I have traced during the interviews can be referred to selective style. It consists of random conversations of the adults, communication with other people, and accusation in betrayal. Greta Uehling mentions that it happened often when someone outside a family tell children about deportation. ${ }^{3}$ Lenura remembers that Crimean Tatars were called "traitors" at primary school. She asked her mom why they were traitors and mother told her about the deportation. She believes that it was the first time when she realized that her nation was living not in the homeland. ${ }^{4}$ Nadiye recalls that she was 10 or 11 years old when a Russian schoolgirl called her "traitor":

There was a girl at school, a Russian girl that called me "traitor". I remember that I grabbed her hair and beat her. Then I went home crying and asked my mother, "Mom, why did she call me a traitor?" Obviously, the girl's mother came to us and said, "Your daughter beat my daughter." And I said, "You'd rather ask her why I did it. Your daughter called me a traitor. Whom and what have I betrayed?"5

Shefika states that her parents protected her from knowledge about deportation, but nevertheless she heard from them every time, "Qirim, Qirim". She explains that "Crimea was like a promised land".

\footnotetext{
${ }^{1}$ Uehling, Beyond memory, 14.

2 Ibid., 116.

3 Ibid., 116.

${ }^{4}$ Lenura, 1946

${ }^{5}$ Nadiye, 1951. Interview by author. 9 January 2014
}

She specifies that she understood what had happened with her nation only when she grew up. ${ }^{6}$

Elvira realized the "tragedy of her nation" when she was twelve, because her classmate had moved to Crimea with her father, Musa Mamut, who later had burnt himself down as an act of protest against oppression of Crimean Tatars. ${ }^{7}$

Another part of testimonies can be referred to intensive style of cognition. It is closest to bedtime and mealtime stories. For example, some Crimean Tatars do not know tales because they were told stories about deportation and Crimea by grandma.

I told my children about Crimea because they were asking. And after that they sang songs about Homeland in kindergarten. ${ }^{8}$

Hulsum states that she was told about living in exile in her childhood. Her father emphasized that their family would come back home to Crimea, because it is their motherland. ${ }^{9}$ Rustem says that in Crimean Tatar families the elder people always underlined that their homeland is Crimea, yet they ought to live in Uzbekistan against their will. ${ }^{10}$ Zera remembers that the deportation and related issues were constantly discussed in family. ${ }^{11}$ Remziye, born in 1958, says that consciousness about living in exile came with "mother's milk":

Elders often gathered and remembered their childhood, life in Crimea, and we are happy to listen. But we do not understand why we do not live where our parents spent their childhood. Children from an early age knew that Central Asia is not our land. ${ }^{12}$

Lastly, some testimonies can serve as good examples of silent narrative, reluctant style of cognition, as Greta Uehling mentions "the style of selective recounting was employed to avoid pain". ${ }^{13}$ There were families that were afraid of persecution or tried to avoid emotional pain. Revziye says that nobody told children about the deportation..$^{14}$ Ava-Sherfe remembers that she began discovering the history of her nation only when she was in college. ${ }^{15}$ Ulker recalls that she heard about the deportation when she was 15 -year-old for the first time. She tells that her father protected them from this trauma, although he

\footnotetext{
${ }^{6}$ Shefika, 1950.

${ }^{7}$ Elvira, 1962. Interview by author. 9 January 2014.

${ }^{8}$ Usta, 1934. Interview by author. 12 August 2015.

9 Hulsum, 1954. Interview by author. 8 January 2014.

${ }^{10}$ Rustem, 1951. Interview by author. 8 January 2014.

${ }^{11}$ Zera, 1959.

${ }^{12}$ Remziye, 1958. Interview by author. 9 January 2014

${ }^{13}$ Uehling, Beyond memory, 116.

${ }^{14}$ Revziye, 1953. Interview by author. 10 January 2014.

${ }^{15}$ Ava-Sherfe, 1953. Interview by author. 9 January 2014.
} 
had "a special folder with some materials". of respondents understand themselves as Crimean Tatars while trying to apply to a college or a university, as higher education was forbidden for them during the first decades of exile:

After school I was not able to enter a college, because it was forbidden for Crimean Tatars to obtain higher education in exile. So, I started my job in a kindergarten. It was really hard to get a job in those times. We were despised. ${ }^{2}$

Those Crimean Tatars who experienced the deportation remember that in the beginning it was hard to believe that it was Stalin who unfairly punished all the people without evidence and the punishment was too offensive. Self-perception as being unfairly punished led to the emergence of the victim identity linked with the feeling of anger. Such a trend corresponds with the periodization of the so-called National Movement. If right after the deportation Crimean Tatars activists asking for return (so-called Letter-Writing) tried to persuade authorities that they were innocent, afterwards when a new generation has grown up, they struggled for their right to return to Homeland.

The Soviet authorities tried to remove even the word "Crimean" from "Crimean Tatars" to facilitate assimilation. Greta Uehling writes in her book that "they were Crimean Tatars, but they must live outside the Crimea; they were exiled for being Crimean Tatars, but there is no such a nation". ${ }^{3}$ Crimean Tatars did not have certain solution to this dilemma. After cancellation of special settlements regime in 1956, it became clear that the Soviet authorities would not let them return to their homeland and the idea of returning was rather a utopia.

I often asked, why Crimean Tatars danced Russian, Ukrainian, Kazakh dances on various holidays. Why don't they dance in Crimean Tatar style? I asked my mom and she replied that we had been deported and Crimean Tatars did not have their own People's Republic like others do. And I remember that when a census took place in the Soviet Union, they asked us, "Who are you?", and we used to reply "Crimean Tatars", but they wrote down just 'Tatars'.

Common goal and solidarity with collective trauma united Crimean Tatars. Previously, before the deportation, Crimean Tatars had their own Oth-

\footnotetext{
1 Ulker, 1968. Interview by author. 28 October 2013.

2 Anonym, 1949. Interview by author. 30 July 2017.

${ }^{3}$ Uehling, Beyond memory, 39.

4 Zuriye, 1968.
}

ers inside the nation, but in exile there was no othering inside the community. Ostracism was practiced only against those who betrayed common interests

On a trial a Crimean Tatar man said that he did not know Russian language (but he knew, of course), so the court tried to find someone. And a Crimean Tatar woman agreed to translate. Afterwards no one talked to her, she was being cursed. ${ }^{5}$

I argue that Homeland was a detriment element for Crimean Tatar identity in exile. Initially, Crimea was perceived as their lost paradise; then as a promised land after they made attempts to come back to the peninsula. As some researchers argue, traditional culture, language, and religion can be unstable, but the topos of lost Homeland is a powerful consolidating factor. ${ }^{6}$

While constructing an imagined Homeland, Crimean Tatars looked for ordinary things in exile resembling those that they had seen and tasted in Crimea: "There were long conversations on the taste of Crimean well water, and the strength of the Crimean sun. Some members of the second generation had a metaphysical theory that the molecules of the Crimean fruits and vegetables their parents had eaten became a part of their bodies". 'Shefika remembers that her parents used to compare everything with Crimea, so they repeated all the time, "Everything was different in Crimea":

When we sat down at the table, my parents took the grapes and said, "Is it supposed to be called grapes? There were grapes in Crimea. Is it supposed to be called an apple? There were apples in Crimea." If somebody returned from Crimea, he brought flask with water. While swimming in the sea, they took some water; while transporting that water it became rotten. "This water is of the Black Sea!" When one was ill, he was given that water. It was said that everything was different there... Everything was glorified. It was even said that the taste was different. When I returned to Crimea, I did not like fruits because they were waterish and tasteless. There is more sun in Uzbekistan, they are sweeter and more fragrant. ${ }^{8}$

Looking for similarities in surroundings and feeling nostalgia about uniqueness of homeland is a common narrative for exiles and deportees. For instance, Hisham Sharabi, Palestinian living in US says that looking for a smell of a green thyme, taste of a grape, view of a seashore constantly helps him

\footnotetext{
5 Ediye, 1963 .

${ }^{6}$ Олена Соболева, “Формування образу етнічної батьківщини кримських татар в умовах репатріації та облаштування в АР Крим,” Матеріали до української етнології 10 (2010), 45.

7 Uehling, Beyond memory, 115.

${ }^{8}$ Shefika, 1950.
} 
to imagine Jaffa and Beirut. ${ }^{1}$ Those exiles who had an opportunity to visit Homeland for a short period of time tried to take some water or fetch some soil to share it with compatriots in Uzbekistan. ${ }^{2}$ Zera says that Crimea was for her like a magic country Susambil from Uzbek fairy tales, which she used to read:

That was really fantastic Susambil country with the sea, palm trees, cypresses and this fertile land. Unusual country, very beautiful, with warm climate. Our father always compared everything with the Crimean one. When we bought tulips, he said, "Oh! What the tulips in Crimea!" Crimea therefore has always been perceived a country Susambil, fairyland. ${ }^{3}$

Memory of Crimea (individual or inherited) was an appeal to leave everything and return to Crimea illegally. Such an aspiration to return had a biological connotation, because Crimean Tatars understood themselves as an essential part of Homeland, deeply rooted and the exile had ruined this connection. For example, Mumine Karabash after return to Crimea in 1968 named her son Vatan (Homeland). ${ }^{4}$ Lyomar also was among the first returners to Crimea in the $1960^{\text {th }}$

I used to wake up each night because I was dreaming about Crimea, those places where I used to play when I was a child. In the morning I went to work hoping to sleep after that, but at night everything repeats. Grandma used to talk about Crimea a lot too. And to be honest, I could no longer live without Crimea. ${ }^{5}$

Unfortunately, for early returners everything was not so picture-perfect. A bitter taste of a promised land and everyday struggle for their rights made the Crimean Tatars to face new challenges. Ediye returned to Crimea with her parents in the $1960^{\text {th }}$ when was a little girl, expecting something else, but not a dry steppe in the Northern part of the peninsula.

I remember we took a bus from Simferopol to Kerch and I asked my father "Daddy, where is Crimea?" - "Look, it is Crimea everywhere". I looked out of the windows, but I saw only the steppe. So, I asked him again, "Daddy, where is Crimea?". To be honest, I was shocked. You know, we had lived pretty well in Uzbekistan. My father

\footnotetext{
${ }^{1}$ Helena Schulz, Juliane Hammer, The Palestinian diaspora: Formation of identities and politics of homeland (London and New York: Routledge), 94.

2 Ibid., 99.

${ }^{3}$ Zera, 1959.

${ }^{4}$ Vatan, 1970. Interview by author. 26 August 2018.

${ }^{5}$ Lyoman, 1938. Interview by author. 13 August 2017.
}

had built a new house for us. Instead, in Crimea we had bitter water in our well. ${ }^{6}$

As stated above, according to interviews used in this paper, selective style of learning (waiting, saving from trauma) was the most spread among the second and third generations of deported Crimean Tatars. In addition, the accusation of betrayal was a rife way of learning about deportation and self-perception as deported Crimean Tatars. Nevertheless, the significance of family narratives cannot be underestimated, because the family was the place where imagined Homeland was constructed due to nostalgia and stories about lost paradise. I argue that nostalgia for romanticized Homeland and return wish were constituting key points of Crimean Tatars' self-definition.

\section{Being the Others}

As was mentioned in the beginning, not the whole Crimean Tatar nation were deported to Uzbekistan. Some of them found themselves in Mari ARSR (8597), others were settled in Molotov oblast (10555), Kemerov Oblast (6743), Gorky Oblast (5095), and Sverdlov oblast (3595). ${ }^{7}$ These settlements were called "labor camps" and populated by different deported peoples, dekulakized peasants and political prisoners from all over the USSR. According to Crimean Tatars testimonies and scholars, it was much easier to survive in these areas, first of all due to regular meagre food provisions. Secondly, Crimean Tatars had no conflicts with others "punished" by the Soviet regime, so some kind of solidarity emerged between them. ${ }^{8}$

They saw that we were ordinary people and we began to understand each other. As appeared, all those living there were deported by Communists: kulaks, political exiles... They told us that before our arrival they had been told that people with one eye and horns who eat children would arrive. But then it appeared that we looked like they looked. We lived amicably and peacefully. Then, as we are Crimean Tatars and we make coffee, so my granny treated neighbors with coffee. ${ }^{9}$

It can be supposed that situation in Uzbekistan was similar. There were Koreans, Meskhetians Turks, Greeks, Armenians, Bulgarians deported to Uzbekistan. According to testimonies of Crimean Tatars, they had neither enmity nor misunderstandings with those nations: "There were Kurds, Ko-

\footnotetext{
${ }^{6}$ Ediye, 1963.

${ }^{7}$ Гульнара Бекірова, Півстоліття опору, 101

${ }^{8}$ Brian G. Williams, The Crimean Tatars. The Diaspora Experience and the Forging of a Nation (Boston: Brill, 2001), 391.

${ }^{9}$ Lyoman, 1938.
} 
reans, Meskhetians Turks, Germans, Crimean Tatars, Chechens. I guess, we all have been through enough". ${ }^{1}$

At the same time relations with the local population, Uzbeks, were not so good at the first years of exile. Unfortunately, Crimean Tatars received "cold welcome" from the native population. ${ }^{2}$ In historiography, narratives of Crimean Tatars, and literature it was local population, Uzbeks who accused Crimean Tatars to be traitors or were hostile to them.

Mother said that once she had been caught collecting the spikelets. Warder had taken pity on her and hit just once. It turns out he could beat her to death and he would have nothing for it. ${ }^{3}$

Such testimony is typical for deportation narrative. An extremely popular among Crimean Tatars author Valeriy Vozgrin, whose book titled 'Historical fates of Crimean Tatars' is an example of narrative accepted by the community, gives a bunch of testimonies recorded by Mejlis concerning Uzbeks and their attitude to exiles. There are memoirs about discrimination, oppression, robbery, murders, and rapes committed by Uzbeks. At the same time author writes that he can mention only few stories about Uzbeks helping Crimean Tatars, "but maybe there are more". ${ }^{4}$ It is usually said that such a terrible situation lasted until Uzbeks understood that Crimean Tatars "were not traitors, didn't have horns and were Muslims too". Or until Crimean Tatar men returned from the army in 1948, because locals began to see a gap between the Soviet official propaganda (the whole nation are traitors) and reality (war veterans with medals). ${ }^{5}$ Crimean Tatars thus were not accepted as "brothers in faith" by local population.

According to interviews, in places of resettlement of deported Crimean Tatars the local authorities and NKVD spread rumors about them being traitors, deserters, and monsters. Brian Williams, relying on his own fieldwork, argues that this propaganda was effective because "Uzbek kolhoznik had a xenophobic distrust of outsiders". ${ }^{6}$ Unfortunately, we have no evidence by which we may be able to trace how and by whom the myth about Crimean Tatars as traitors transformed into the myth about them as one-eyed and horned beasts eating babies.

\footnotetext{
Shefika, 1950 .

Williams, "A community reimagined," 237.

3 Abdripi, 1962. Interview by author. 1 August 2015.

${ }^{4}$ Валерий Возгрин, Исторические судьбы крымских таmap, Том 4 (Симферополь: Картбаба продакшн, 2014), 274.

5 Paul Michael Stronski, "Forging a Soviet city: Tashkent, 1937-1966" (PhD diss., Stanford University, 2003), 199.

${ }^{6}$ Williams, The Crimean Tatars. The Diaspora Experience and the Forging of a Nation, 391.
}

Probably, it was created by Soviet propaganda and accepted by locals without doubts. The stories about Uzbeks meeting them with stones because they had been told that "the horned people would arrive" are also a common and widespread feature in the narratives of Crimean Tatars:

People were hardly civilized there. They believed everything they were told. We have remained for them scoundrels. My whole life I heard this, 'Scoundrel!' This is how we were called till the end. A railway bridge burned down. And who did it? Tatars! A cow died - Tatars! You are accused absolutely unfair, but you cannot do anything. He just calls you 'Tatar!' - and puts all the hatred and anger in this world.?

An accusation of betrayal, the core component of the life of Crimean Tatars in exile, used to take place even in the 1950s and later. The accusation could have been said by other, non-Crimean Tatars in order to offend them: "You, Tatars, are betrayers", "You are traitors." Yet the signs of accusation have nearly disappeared in the recollections of Crimean Tatars born in the 1960s. Perhaps, the phenomenon was widespread in the countryside, where deported Crimean Tatars were initially settled, and where such a negative image of Crimean Tatars was artificially created by the Soviet state`s propaganda.

Furthermore, Soviet propaganda also used WWII as a tool of disinformation and manipulation. The locals blamed Crimean Tatars because, from their point of view, Uzbek men were fighting, and Crimean Tatars were hiding:

The locals used to say: "Ours are fighting, at the same time you are sitting here". When our fathers and husbands returned from the war Uzbeks were surprised: "Seems like yours also fought". A lot of Crimean Tatars were awarded with medals. Only after the Victory, after returning of our men the attitude towards us became better. ${ }^{8}$

In the narratives of Crimean Tatars about the first years after the deportation, we can find that two opposite types of stories are peacefully coexisted, namely about the help from the local population and their unfair treatment of Crimean Tatars. For instance, having been kept short of food, Uzbeks shared their food and groceries with the exiles.

Some mullah rejected to sell one kilo of corn for 90 rublis. He asked 95 , but we did not have 5 rublis. Although our neighbors were good people. They invited us in winter and share their food. ${ }^{9}$

\footnotetext{
${ }^{7}$ Zevid, 1939. Interview by author, 10 August 2017.

${ }^{8}$ Nazim, 1936. Interview by author, 10 August 2017.

9 Hayire, 1929. Interview by author, 9 August 2017.
} 
The othering of Crimean Tatars by Uzbeks was initiated not only through the Soviet propaganda, but also due to the cultural differences. As Crimean Tatars saw themselves more connected with Europe than Asia ${ }^{1}$ due to the shift in their national identity in the beginning of the $20^{\text {th }}$ century, they were surprised by the level of domestic culture of the local population. For instance, having been used to drinking coffee, Tatars suffered from Uzbek tradition to drink tea only. Moreover, local population didn 't cut a carcass in the way like we do.

When you go to the market, you ask an Uzbek in his language to give a certain piece that you need, for example tenderloin. But they do not cut meat like we do, so he just chops a part of it along with bones and says, 'Go to your Crimea and give your orders there'. We were different in terms of household chores. We had everything clean, painted, whitewashed, and tidy. ${ }^{2}$

According to testimonies, in contrast to Uzbeks Crimean Tatars were trying to keep their house clean and tidy, despite living conditions that were awful in special settlements, that surprised the locals and distinguished them from Uzbeks.

My mother told me that when they had arrived they had received a dwelling, but it was dirty. Then my grandpa had leveled everything with a clay overnight, and grandma had whitewashed it, made the floor, and hung curtains. On the next day, an Uzbek landlady had come to us, seen the house, and said, "It is so nice here! Leave the house!" Next household that we received was a shed. And the same story. Then my grandpa said to my grandma, "Do not make it nice, give us a chance to live here a little! Because they will move us out again!"”3

According to some Crimean Tatars, this cultural difference was beneficial for the locals, who adopted some elements of their everyday customs. The othering of Crimean Tatars therefore has been eventually accepted by Uzbeks.

Then I saw that Uzbeks began adopting our customs. They really liked our weddings, especially music. When we left Uzbekistan, they said, 'What will we do without you?' Sometimes they reproached us for being strangers, 'You came here in railway cars, we wish you would go away'. But normal people understood that we were the hostages to the situation. $^{4}$

${ }^{1}$ Williams, The Crimean Tatars. The Diaspora Experience and the Forging of a Nation, 393.

2 Nadiye, 1951.

3 Zuriye, 1968

4 Osman, 1967.
What was the nature of perception Crimean Tatars as the Others? Due to the lack of official documents no one can say for sure whether Crimean Tatars were deported to Uzbekistan on a special purpose. Nevertheless, it is a common belief that Crimean Tatars were placed to Uzbekistan for profound assimilation, because the Uzbeks are also Muslims by faith and, more important, speak similar language that belongs to the same language family of Turkic languages ("Intention of the Soviet state was assimilation, not annihilation"s). Moreover, as was mentioned above, the Soviet authorities tried to remove the "Crimean" from the "Tatar" to encourage assimilation.

Nevertheless, Crimean Tatars did not assimilate with Uzbeks because there were too many differences between them by the moment when Crimean Tatars were placed to Uzbekistan. Paradoxically, religion was one of the elements distinguishing Crimean Tatars from Uzbeks. As indicated previously, a shift toward secular and ethnic identity had been completed in Crimea far earlier than in Muslim Central Asia. ${ }^{6}$ Although the idea of new schooling of Ismail Gaspirali has reached Bukhara, probably it was not well-known in distant kishlaks of Uzbekistan. Concerning the impact of the Soviet state's antireligious propaganda, Crimea in the pre-war period was a populous and urbanized region with powerful local authorities, including Veli Ibrahimov, and influential policy of korenizatsia, whereas in Uzbekistan the Soviet Union was fighting with basmachi movement (defeated by 1931) by the hands of local Muslim peasants. ${ }^{7}$ Attempts to reduce the impact of Islam and native traditions in Uzbekistan were not successful, because Central Asian communists remained unaware of the goals of the Soviet transformation and tried to combine their identities as Muslims and Communists. ${ }^{8}$ Moreover, the influence of Islam had increased during the wartime. ${ }^{9}$ As Crimean Tatars recall, Uzbeks did not treat them as Muslims; moreover, they criticized exiles for the wrong type of Islam ("Girls with covered faces used to threw stones at our women saying 'Pantless ${ }^{10}$ Russians!"'11). According to some testimonies, locals started to accept exiles when Crimean Tatars

5 Uehling, Beyond Memory, 231

Williams, "A Community Reimagined," 234.

Shirin Akiner, "Uzbekistan and the Uzbeks," in The Nationalities Question in Post-Soviet States, ed. Graham Smith (London and New York: Longman, 1990), 335.

8 Stronski, "Forging a Soviet city," 34.

9 Ibid., 285.

${ }^{10}$ In Central Asia, women used to wear pants under a dress or robe to hide their body completely.

11 Эдие Муслимова, ред., Депортаиия крымских татар 18 мая 1944. Как это было (Симферополь: Оджакъ, 2004), 101. 
began to stress their common Islamic beliefs. ${ }^{1}$

Therefore, it can be assumed that by the mid of the $20^{\text {th }}$ century the most advanced identity for local population of Uzbekistan was religious one. For example, the Uzbek woman interviewed between 2005 and 2007 in Bukhara said that she felt anger when she was asked about her ethnicity, because she and her ancestors belonged to a certain village in olden days and to a certain kolhoz in Soviet times. ${ }^{2}$ By the moment of deportation Crimean Tatars already had their ethnic-based identity. The identity can be inherited if it is powerful, attractive, may bring benefits or imposed by force. The only reason for Crimean Tatars to follow Uzbeks was a language by which it was possible to resist Russification. Unfortunately, the level of education in Uzbek schools was extremely weaker than in Russian-speaking schools. Moreover, Russian culture was on top, in Uzbekistan whereas Uzbek language and culture served only as a decoration in "cotton motif". ${ }^{3}$ Thus, we are heading towards the next factor causing a cultural gap between Crimean Tatars and Uzbeks.

According to Vyatkin and Kulpin, industrialization of Uzbekistan after WWII was a niche occupied by Crimean Tatars, since local population was reluctantly moving to manufacture, remaining engaged in agriculture and traditional way of life. ${ }^{4}$ Moreover, it was cheaper and faster to train workers among well-educated, experienced, and Russianspeaking Crimean Tatars. At first, Crimean Tatar qualified workers were employed in underpaid jobs: "I remember a young man doing the work of the chief accountant, but he was listed on a minor position". ${ }^{5}$ Crimean Tatars were exceptionally hardworking and diligent, so over time they were materially better off the surrounding population": "We started to live better, built a new house and received a plot of land for agriculture"7

Such a state of affairs was typical for a majority of deportees in the Soviet Union. For example, Greeks deported from the Caucasus to Kazakhstan in 1949 specify that after the cancelation of a special regime they moved to urban areas and succeeded in

\footnotetext{
1 Williams, The Crimean Tatars. The Diaspora Experience and the Forging of a Nation, 393.

2 Timur Dadabaev, Identity and Memory in Post-Soviet Central Asia (New York: Routledge, 2016), 26.

3 Stronski, "Forging a Soviet city," 283.

4 Эдуард Кульпин, “Трансформация крымскотатарского этноса (1944-1996)”, Крымские татары: Проблемы репатриации, ред. Аркадий Втякин, Эдуард Кульпин (Москва: Институт востоковедения РАН, 1997), 44.

5 Виктор Бердинских, Спеипоселениы: Политическая ссылка народов Советской России (Москва: Новое литературное обозрение, 2005), 654.

6 Isabelle Kreindler, "The Soviet Deported Nationalities: A Summary And An Update,” Soviet Studies 38, 3 (1986), 399.

${ }^{7}$ Lutfi, 1928. Interview by author. 15 August 2015.
}

education and employment. ${ }^{8}$ According to the testimonies, by the 1960s Crimean Tatars surpassed locals in educational and economic terms ${ }^{9}$. For example, Lutfi recalls that his family luckily escaped special settlement and by 1946 he already was a high-level machinist (tokar sedmoro razryada)

I was 16 years old when I was sent to teach machinists, because I was a highly-qualified worker. Uzbeks brought their children: "Look at him! Learn from him!". On some of the motor depot, the drivers were completely Crimean Tatars, their trucks worked like new ones. Uzbeks were shocked! They started to look at us differently. They began to invite us on weddings, block parties, for a plov occasion, we started to live better together. We became specialists number one in Uzbekistan. Moreover, doctors and professors started to emerge. ${ }^{10}$

First of all, this new gained status was important for Crimean Tatars not because of prestige and symbolic membership in Soviet society, but because it was an opportunity to improve livelihoods and living conditions. A similar account about escaping from poverty was recorded by Timur Dadabaev in Uzbekistan in 2007:

My mother was left completely alone and her first work was to cut the trees. She then got a job in a kolkhoz. Since my mother attended seven classes of school, she was treated as an educated person. That allowed her to get a job in a boarding school and become a teacher. She also spent a lot of time working because she wanted to do everything to escape from poverty. Because of her hard work, I could graduate from my school and apply to a medical technical vocational training school. My brother graduated from the Tashkent Technological University. I remember the way we lived our life having only one thing in our minds "to live from one day to another and survive." When each day passed, we thought "it is so good that today has finished without problems." 11

The role of education cannot be underestimated. As was mentioned above, the situation with schooling in Uzbekistan in a post-war period was deplorable. Due to the shortage of schools and teachers, the exiles even tried to establish schools by themselves in remote kishlaks. Unfortunately, the local population was indifferent to their education: in 1948, only $33.5 \%$ of the Uzbek girls studied in school in Tashkent, one of the leading regions in the female

\footnotetext{
${ }^{8}$ Violetta Hionidou, David Sanders, "Exiles and Pioneers: Oral Histories of Greeks Deported from the Caucasus to Kazakhstan in 1949," Europe-Asia Studies 62, 9 (2010): 1494.

${ }^{9}$ Williams, "A Community Reimagined," 239.

${ }^{10}$ Lutfi, 1928.

${ }^{11}$ Dadabaev, Identity and Memory in Post-Soviet Central Asia, 56.
} 
education in Uzbekistan. ${ }^{1}$ Crimean Tatars took the lead by increasing the education level and forcing the knowledge of Russian language: "The severity of existence pushed our youth to the colleges, because if you are educated well, you and your children will be well-off in the future". ${ }^{2}$ Exiles did not want to send their children to Uzbek schools, because education and social status were necessary measures to prove their innocence, reveal diligence and reliability.

Crimean Tatars were trying to study twice as hard to prove that we are the best. Because if we are on the same level with Uzbeks, we will not be able to enter a college. And the same was concerning Russian language. Thanks to parents, because parents were trying to provide higher education, no matter either medical college or pedagogical one. ${ }^{3}$

By the end of the 1980s, Crimean Tatars among with Russians and other Russian-speaking groups occupied the majority of knowledge-intensive sectors of industry thanks to language and education, while less knowledge-intensive service-related occupations contained a large percentage of Uzbeks. ${ }^{4}$ Moreover, $69 \%$ of Crimean Tatars in Uzbekistan lived in cities. ${ }^{5}$ Therefore, Russification or Sovietization (White man's burden, in colonial terms) of Crimean Tatars was a result of the shift from the oppressed minority toward a full member of the Soviet Central Asian society. As Vyatkin and Kulpin state, Uzbeks treated Crimean Tatars like Russians. ${ }^{6}$ Moreover, Uzbeks in interviews conducted in the 1990s recognized the arrogance of the Crimean Tatars and their contempt for locals, since former exiles acted like Russians. ${ }^{7}$

According to Ackermann such a process of social acculturation can be determined as Autosovietization, because it was not a result of a full-scale practice of Russification implemented by authorities, but a matter of prestige and effect of urbanization and modernization. ${ }^{8}$

Nevertheless, despite the rapid change in their social status, Crimean Tatars remained second-class citizens, because they still were labeled as traitors ("You came in Uzbekistan in boxcars, it will be bet-

\footnotetext{
1 Stronski, "Forging a Soviet city," 281.

2 Rasim, 1939. Interview by author. 10 January, 2014

${ }^{3}$ Osman, 1967 127.

${ }^{4}$ Dadabaev, Identity and Memory in Post-Soviet Central Asia,

5 Аркадий Вяткин, “Среднеазиатский тупик: причины возникновения, маштабы, пути выхода", Крымские татары: проблемы репатриации, 124. Moskva, 1997.

6 Эдуард Кульпин, “Трансформация крымскотатарского этноса (1944-1996)”, Крылмские татары: Проблемы репатриациии, 44, 46.

${ }^{7}$ Вяткин, “Среднеазиатский тупик”, 124.

${ }^{8}$ Felix Ackermann, "Autosovietization. Migration, Urbanization and Social Acculturation in Western Belarus," Jahrbücher Für Geschichte Osteuropas, Neue Folge 64, 3 (2016): 409-436.
}

ter if you go away as soon as possible" $\left.{ }^{\prime 9}\right)$. Uzbeks expressed anger that Tatars were sent to such a good place as Uzbekistan, they should have been sent to Siberia for their crime against Motherland instead. Locals feared that the Tatars exile is only a start and Uzbeks and Russians soon would be removed from certain parts of Uzbekistan. ${ }^{10}$ Furthermore, for those Russians living in Uzbekistan Crimean Tatars served as a buffer between themselves and local population. ${ }^{11}$ Crimean Tatars found themselves "inbetween": in exile far from Homeland, too good to be Uzbeks (according to testimonies), not innocent to be Russians.

\section{Conclusion}

The deportation ruined the traditional way of life, social structure and cultural institutes of Crimean Tatars. Even religion, one of the significant parts of their life, was diminished due to the Soviet antireligious policy and fear of persecution for performing rites. Nevertheless, Crimean Tatars were able to keep a certain number of traditions inherent in Islam as their everyday practices and, moreover, turn Soviet holidays from being imposed by the state into their own festivities through the establishment of new rituals not always related to the dominating ideology of the Soviet Union. Family played a leading role in keeping traditions in exile. Unfortunately, in a fight with Russification family became a last stronghold, because schooling was primary in Russian. Therefore, nowadays Crimean Tatar language is limited to the domestic sphere. On the other hand, compelled Russification was the only way to change a social status in exile.

Despite widespread understanding of identity as a set of cultural and ethnical features, we can see that in the case of Crimean Tatars as an exiled community religion and culture played less significant role than nostalgia for their lost home and eagerness to Return to the Homeland. The trauma of forcible exile increased the link between Crimean Tatars and Homeland and played a significant role in a collective imagination of community and self-definition. Moreover, an actively maintained collective memory about their lost Homeland is a fundamental element of community distinct identity. ${ }^{12}$ The role of family in preserving the image of Crimea in narratives also cannot be underestimated. Parents told

\footnotetext{
${ }^{9}$ Osman, 1967.

${ }^{10}$ Stronski, "Forging a Soviet city," 196.

${ }^{11}$ Кульпин, “Трансформация”, 46.

${ }^{12}$ Khachig Tölölyan, "Rethinking Diaspora(s): Stateless Power in the Transnational Moment", Diaspora: A Journal of Transnational Studies 5, 1 (1996): 13.
} 
their children about Crimea, describing it as the promised land or Yeşil Ada (the Green Island). The deported people compared exquisite scenery and temperate climate of the peninsula to waterless steppes of Uzbekistan. Comparing two territories, they pictured even an arid steppe as a flourishing land between the Black Sea and the Azov Sea. Trauma of deportation became an essential part of Crimean Tatar self-perception, which resulted in giving birth to as many children as possible (to compensate the loss) by the generations born in exile after the deportation and naming kids after deceased ancestors. Lastly, I argue that an identity of exiled Crimean Tatar was based on a collective yearning to return to their Homeland.

Although Crimean Tatars are Muslim by faith and speak similar with Uzbeks language, expected assimilation did not occur. Moreover, Crimean Tatars were treated as Others by Uzbeks due to the Soviet propaganda that provoked aggressive other- ing and dehumanization of Crimean Tatars in exile, as well as socio-economic and cultural differences between the two nations. Nevertheless, by the end of the 1980s with the collapse of the Soviet Union interethnic relations in Central Asia got worse and conflicts had become violent. As seen, the othering of Crimean Tatars as 'traitors' and 'not right Muslims' in the first years after the deportation was replaced with othering by social and economic reasons. According to the historiography, there is a common belief that with Russification Crimean Tatars in exile inherited a white man's burden. At the same time, by drawing on the narratives of Crimean Tatars, we can conclude that they thought of themselves as more European and civilized from the very beginning of their exile in Uzbekistan than the Uzbeks. Paradoxically, in exile Crimean Tatars were treated as Russians, after their returning home they became Asians as evidenced by a long history of conflicts with the Russian community in Crimea.

\section{Bibliographic References}

Abdripi, 1962. Interview by author. 1 August 2015

Ackermann, Felix. "Autosovietization. Migration, Urbanization and Social Acculturation in Western Belarus." Jahrbücher Für Geschichte Osteuropas, Neue Folge, 64, 3 (2016): 409-436.

Akiner, Shirin. "Uzbekistan and the Uzbeks." In The Nationalities question in Post-Soviet States, ed. by Graham Smith, 334-347. London and New York: Longman, 1990.

Altan, Mubeyyin. "Structures: The importance of family - the personal memoir." In The Tatars of Crimea: Return to the Homeland, edited by Edward Allworth, 99-109. Durham and London: Duke University Press, 1998.

Anonym, 1949. Interview by author. 30 July 2017.

Ava-Sherfe, 1953. Interview by author. 9 January 2014.

Aydıngün, Ayșegül, Yıldırım, Erdoğan. "Perception of Homeland among Crimean Tatars: Cases from Kazakhstan, Uzbekistan and Crimea," Bilig, 54 (Summer 2010): 21-46.

Bazhan, Oleg, ed. Krymski tatari: shlyah do povernennya. Kyiv: Institute of Ukrainian history, 2004.

Bekirova, Gulnara. Krimskotatarskaya problema v SSSR (19441991). Simferopol: Odzhak, 2004.

Bekirova, Gulnara. Pivstolitya oporu: Krimski Tatari vid vignannia do povernennia (1941-1991 roki). Naris politichnoi istoriyi. Kyiv: Krityka, 2017.

Berdinskih, Viktor. Spetsposelentsi: Politicheskaya ssilka narodov Sovetskoy Rossiyi. Moskva: Novoe Literaturnoe Obozrenie, 2005.

Bugai, Nikolay, ed. Iosif Stalin - Laverentiiu Berii: “Ikh nado deportirovat” dokumenty, fakty, kommentarii. Moscow: Druzhba narodov, 1992.

Dadabaev, Timur. Identity and Memory in Post-Soviet Central Asia. New York: Routledge, 2016.

Ediye, 1963. Interview by author. 15 August 2015.

Elvira, 1962. Interview by author. 9 January 2014.

Fisher, Alan. The Crimean Tatars. Stanford: Hoover Institution press, 1978.

Gülüm, Riza. "Rituals: Artistic, Cultural, and Social Activity." In The Tatars of Crimea: Return to the Homeland, ed. by Edward Allworth, 84-97. Durham and London: Duke University Press, 1998.
Hall, Mica. "Russian as spoken by Crimean Tatars." PhD diss., University of Washington, 1997.

Hayire, 1929. Interview by author, 9 August 2017.

Hionidou, Violetta and Sanders, David. "Exiles and Pioneers: Oral Histories of Greeks Deported from the Caucasus to Kazakhstan in 1949." Europe-Asia Studies 62, 9 (2010): 1479-1501.

Hulsum, 1954. Interview by author. 8 January 2014.

Kelly, Catriona and Sirotkina, Svetlana. "Bilo neponyatno i smeshno: Prazdniki Poslednih Desyatiletiy Sovetskoy Vlasti i Vospriyatie ih Detmi." Antropologicheskiy Forum 8 (2008): 258-299.

Kreindler, Isabelle. "The Soviet Deported Nationalities: A Summary And An Update.” Soviet Studies 38, 3 (1986): 387-405.

Kulpin, Eduard. "Transformatsia Krimskotatarskogo etnosa (19441996)." In Krimskie tatari: Problemi repatriatsii, ed. by Arkadiy Vyatkin and Eduard Kulpin, 38-50. Moskva: Institut vostokovedenia RAN, 1997.

Lenura, 1946. Interview by author. 9 January 2014.

Liliya, 1953. Interview by author. 10 January 2014.

Lutfi, 1928. Interview by author. 15 August 2015.

Lyoman, 1938. Interview by author. 13 August 2017.

Muslimova, Ediye, ed. Deportatsia Krimskih Tatar 18 Maya 1944. Kak eto bilo. Simferopol: Odzhak, 2004.

Nadiye, 1951. Interview by author. 9 January 2014.

Nariman, 1962. Interview by author. 15 August 2015

Nazim, 1936. Interview by author, 10 August 2017.

Osman, 1967. Interview by author. 12 August 2015.

Pohl, J. Otto. Ethnic Cleansing in the USSR, 1937-1949. Connecticut: Greenwood press, 1999.

Pohl, J. Otto. "The Deportation and Fate of the Crimean Tatars". Paper presented at the 5th Annual World Convention of the Association for the Study of Nationalities, New York, April 2000.

Rasim, 1939. Interview by author. 10 January, 2014.

Refat, 1975. Interview by author. 29 July 2015.

Remziye, 1958. Interview by author. 9 January 2014.

Revziye, 1953. Interview by author. 10 January 2014

Rustem, 1951. Interview by author. 8 January 2014.

Schulz Helena, Hammer, Juliane. The Palestinian diaspora: Formation of identities and politics of homeland. London and New York: Routledge, 2003. 
Shefika, 1950. Interview by author. 10 August 2015

Soboleva, Olena. "Formuvannya obrazu etnichnoi batkivshini krimskih tatar v umovah repatriaziyi ta oblashtuvannya v AR Krim." Materialy do Ukrainskiyoi Etnologiyi 10 (2010): 44-51.

Soboleva, Olena. "Islamski tradiciyi u vesilli krimskih tatar kinzya 19 - pochatku 20 stolittya." Etnichna Istoria narodiv Evropy 25 (2008): 74-81.

Stronski, Paul Michael ."Forging a Soviet city: Tashkent, 19371966." PhD diss., Stanford University, 2003.

The Tatars of Crimea: Return to the Homeland, ed. Edward Allworth. Dukham and London: Duke University Press, 1998.

Tölölyan, Khachig. "Rethinking Diaspora(s): Stateless Power in the Transnational Moment." Diaspora: A Journal of Transnational Studies 5, 1 (1996): 3-36.

Uehling, Greta. Beyond memory: the Crimean Tatars'deportation and return. New York: Macmillan, 2004

Uehling, Greta. "Having a Homeland: Recalling the Deportation, Exile and Repatriation of Crimean Tatars to their Historic Homeland." PhD diss., University of Michigan, 2000.
Ulker, 1968. Interview by author. 28 October 2013.

Usta, 1934. Interview by author. 12 August 2015

Venera, 1959. Interview by author. 30 October 2013.

Vozgrin, Valeriy. Istoricheskie sudbi Krimskih Tatar, Tom 4. Simferopol: Kartbaba prodaksh, 2014.

Vyatkin, Arkadiy. "Sredneaziatskiy tupik: prichini vozniknoveniya, mashtabi, puti vihoda." In Krimskie tatari: Problemi repatriatsii, edited by Arkadiy Vyatkin and Eduard Kulpin, 120-133. Moskva: Institut vostokovedenia RAN, 1997.

Williams, Brian G. "A Community Reimagined. The Role of 'Homeland' in the Forging of National Identity: The Case of the Crimean Tatars." Journal of Muslim Minority Affairs 17, no. 2 (2007): 225-252.

Williams, Brian G. The Crimean Tatars. From Soviet genocide to Putin 's conquest. New York: Oxford University Press, 2016.

Williams, Brian G. The Crimean Tatars. The Diaspora Experience and the Forging of a Nation. Boston: Brill, 2001.

Zera, 1959. Interview by author. 30 October 2013.

Zevid, 1939. Interview by author, 10 August 2017.

Zuriye, 1968. Interview by author. 29 July 2017.

Кислий M.-O.

\section{КРИМСЬКІ ТАТАРИ В УЗБЕКИСТАНІ: МІЖ СПІЛЬНИМ ТА ІНШУВАННЯМ}

Унаслідок депортаџії кримські татари перестали існувати як нація для режиму і стали небажаними сусідами для місиевого населення Узбекистану. Виселення зруйнувало традииійний спосіб життя, структуру суспільства та культурні інститути кримських татар. Серед чинників, що відіграли значну роль у збереженні начіональної ідентичності кримських татар у депортації, традииійні повсякденні практики, свята та релігія посідають помітне місие. Родинні наративи про втрачену батьківщину відіграли важливу роль у збереженні пам'яті про Крим. Разом із тим, родина була місием збереження рідної, кримськотатарської мови, що мало значення в умовах русифікаиіі. Після звільнення зі спецпоселень у 1956 р., кримські татари почали мігрувати у великі міста, в пошуках освіти та прачевлаштування. Культурні відмінності, рівень освіченості та сприйняття віри не дали змоги кримським татарам асимілюватися із місиевим населенням, узбеками. На кінець 1980-х кримські татари, нарівні із росіянами, обіймали головні посади в інтелектуальній сфері та промисловості Узбекистану. Тим не менш, попри таку зміну соціального статусу, кримські татари залишалися «другосортним населенням», «зрадниками» Радянського Союзу.

Ключові слова: кримські татари, Узбекистан, русифікація, ідентичність. 